\title{
Malignant lymphoma of the thyroid
}

\author{
MARIE T. COX \\ From the Thyroid Clinic, the David Lewis Northern Hospital, Liverpool
}

SYNOPSIS Nine cases of malignant lymphoma of the thyroid are described; the clinical features and histological patterns are recorded and the latter related to results of serological tests for thyroid antibodies. The value of such tests in clinical assessment is discussed. The distribution of metastases and their predilection for the gastrointestinal tract is noted.

Malignant lymphoma of the thyroid was for many years a controversial subject but the increasing numbers of well-documented cases in the literature (reviewed by Doniach, 1960, and Roberts, 1961) leave no doubt of its existence as a histological and even clinical entity. However, the histological criteria required for diagnosis, and the relationship of lymphoma of the thyroid to pre-existent primary disease of this gland, particularly struma lymphomatosa, remain debatable.

\section{AGE AND SEX INCIDENCE}

With occasional exceptions, lymphoma of the thyroid affects the elderly woman of an older average age than patients with lymphoma in other situations. The predominance of females has been noted in all series to date (Lindsay and Dailey. 1955; Brewer and Orr, 1953; Walt, Woolner and Black, 1957; Dinsmore, Dempsey, and Hazard, 1949; Welch, Chesky, and Hellwig, 1958; Dick and Kellett, 1951; Metcalfe and Sclare, 1961). This sex incidence contrasts with the male predominance characteristic of either generalized or localized lymphoma occurring in sites other than the thyroid (Harrison, 1960; Evans, 1956; Lumb, 1954). Perhaps this relates to the increased frequency in females of thyroid disease of most types and the greater tendency of the gland in the female to undergo lymphocytic infiltration with increments of age (Goudie, Anderson, and Gray, 1959).

\section{TYPES OF HISTOLOGICAL PATTERN}

Malignant lymphoma of the thyroid can be divided into three types: reticulum cell sarcoma, lymphoblastic immature lymphocytic lymphosarcoma, and lymphocytic lymphosarcoma, all exhibiting the histological features characterizing these tumours in other situations. The value of such a classification is of somewhat doubtful practical value since there may be considerable variation in different parts of the same tumour, and because of the poor correlation between the histological picture and the prognosis even in retrospective analysis (Brewer and Orr, 1953).

In his review of 78 cases from the literature, Roberts (1961) found that one-third were reticulum cell sarcoma, one-third lymphoblastic lymphosarcoma, and one-third mature lymphocytic lymphosarcoma, but he did not relate cell type to prognosis. No convincing record of Hodgkin's disease occurring primarily in the thyroid gland has been found in the literature and benign follicular lymphoma has been rarely described.

The frequency of the histological pattern is again at variance with both systemic malignant lymphoma, in which Hodgkin's disease, lymphosarcoma, reticulum cell sarcoma, and giant follicular lymphoma occur in decreasing order of frequency, and localized lymphoma in which lymphosarcoma and Hodgkin's paragranuloma (indolent form) predominate. Indeed Ewing (1940), Willis (1960), and Warren and Meissner (1953) question the existence of primary thyroid lymphoma. The similarity of the morphological features of malignant lymphoma of the thyroid to those of lymphomas in other sites, however, leaves no doubt of the lymphomatous nature of the thyroid lesions. The distinction from undifferentiated, predominantly round-cell carcinoma is an important one because of the sensitivity of lymphoma to irradiation, the protracted course followed by a proportion of cases of this disease, and the clinical picture which may be presented as a result of the unusual distribution of metastases.

\section{CLINICAL PICTURE}

There are features which present sufficiently often 
in cases of lymphoma of the thyroid to suggest a fairly definite clinical picture. The tumour, often solitary, usually grows fairly rapidly. It may arise in an ostensibly normal thyroid gland, or develop in a previously asymptomatic goitre. As the neoplasm enlarges it occasions progressive obstructive symptoms, often accompanied by profound weakness and a feeling of general ill-health. There is a tendency for the rapidly growing mass to replace the thyroid tissue and eventually to occupy both lobes.

Macroscopically the tumour appears as a diffuse mass of white, pale-grey, pinkish or tan-coloured tissue, sometimes with a pseudo-lobular pattern due to bands of fibrous tissue; rarely does it show a multinodular pattern. The substance may exhibit focal necrosis, haemorrhage, or cystic change. Extension through the capsule of the gland and infiltration of the adjacent tissues with consequent fixation commonly occurs and the regional lymph nodes are often enlarged.

In the nine cases described below the thyroid condition prompted the patient's attendance at hospital. Although the thyroid can be involved as part of a generalized lymphomatous neoplasm there are certain features of these cases that suggest the condition arose primarily in this gland. Six of these patients first presented at the Thyroid Clinic of the David Lewis Northern Hospital, Liverpool, during the years 1952-62, and the details of the other three have been made available by courtesy of colleagues.

\section{CASE REPORTS}

CASE 1 Mrs. D. T., aged 70 years, attended in November 1952 because of a swelling in the right side of the neck. This had been present for 12 months but during the previous two months it rapidly increased in size. There were no obstructive symptoms. There was a nodular enlargement of the right lobe of the thyroid which was hard and fixed to adjacent structures. The cervical lymph nodes were not enlarged. The vocal cords were normal. A radioactive iodine test showed diminished uptake in the area of clinical tumour. The clinical diagnosis was carcinoma of the thyroid.

Operation showed diffuse enlargement of the right lobe of the thyroid which was fixed to vascular structures and had caused displacement of the trachea. Subtotal thyroidectomy was performed.

The histological report was lymphosarcoma.

Clinical reassessment post-operatively showed no generalized disease. In February 1953 radiotherapy in a radical dosage was given to the neck. In April 1953 the patient developed diarrhoea and gastro-intestinal tract metastases were considered as a possible cause but were not found on clinical investigation, which in fact showed diverticulitis. In January 1954 there were enlarged lymph

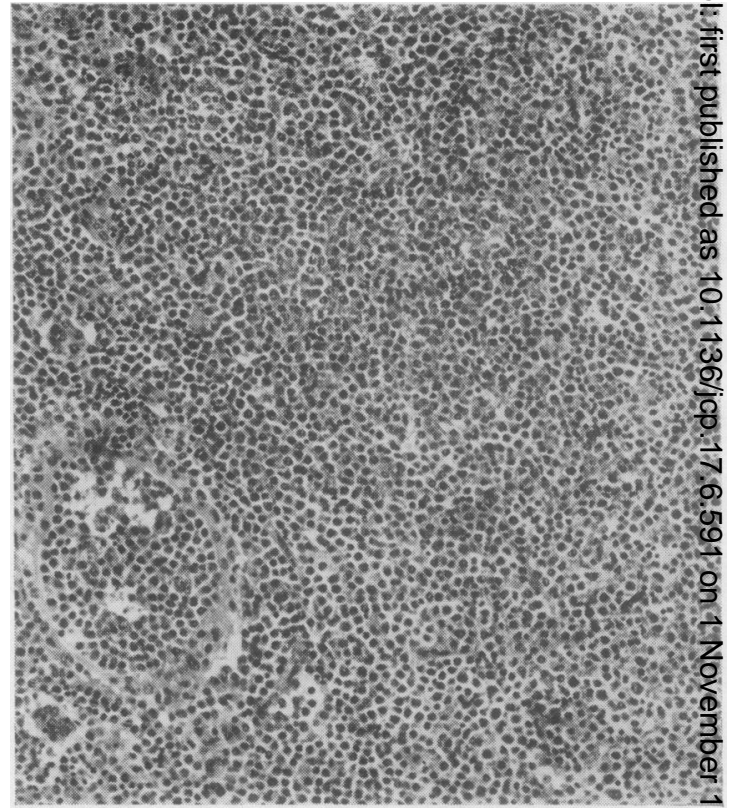

FIG. 1. Case 1: monotonous pattern of proliferatifs tumour cells. Haematoxylin and eosin $\times 110$.

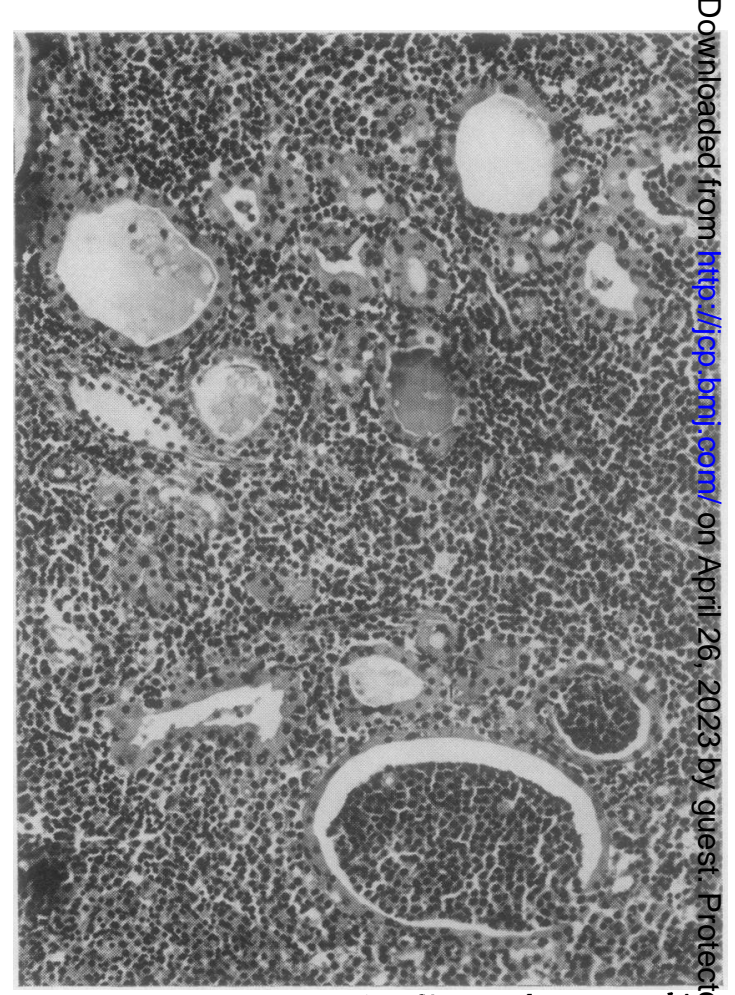

FIG. 2. Case 1: tumour cells infiltrating between and ingo thyroid follicles. Haematoxylin and eosin $\times 110$. 
nodes in the left groin and a biopsy showed a histological picture similar to the thyroid tumour. In February 1955 the patient died elsewhere from congestive cardiac failure with no evidence of local recurrence of the thyroid tumour. A necropsy was not performed.

The patient lived for 27 months from presentation and 39 months from the onset of goitre.

Histology (1530/53) The specimen was of thyroid weighing $105 \mathrm{~g}$.

The sections show uniform replacement of thyroid paranchyma by sheets of reticulum cells and lymphoblasts with small foci of more mature lymphocytes (Fig. 1). The tumour tissue is extending between islands of normal thyroid epithelium and into follicles (Fig. 2) and is infiltrating blood vessels and the capsule of the gland. Within the tumour necrosis and haemorrhage are seen; at the edges of the lesion normal thyroid tissue is present. There is no evidence of Hashimoto's thyroiditis, though some Askanazy change is present.

CASE 2 Mrs. B. H., aged 68 years, attended in January 1954 complaining of swelling of the right side of the neck of one month's duration, associated with respiratory obstruction. A goitre present at the age of 18 years had resolved with treatment.

Examination showed a hard, irregular swelling of the right lobe of the thyroid with fixation to the larynx. A small lymph node was palpable in the posterior triangle. Radiological examination showed tracheal deviation and compression. The diagnosis was carcinoma of the thyroid.

At operation the left lobe appeared normal, and the right contained a mass 2 in. $\times 3$ in. infiltrating muscle. The pale, fleshy, friable, haemorrhagic tumour suggested sarcomatous change. Complete removal was technically impossible; the post-operative course was stormy with severe respiratory distress, and the patient died before radiotherapy could be given.

Histology $(2845 / 54)$ The picture is of sheets of reticulum cells and lymphoblast-like elements (Fig. 3) varying in proportion in different areas, forming large sheets of tissue and infiltrating between thyroid follicles disrupting them and leaving islands of epithelial cells, which in places show Askanazy changes. Thyroiditis is most marked at the advancing edge of the tumour where an incomplete halo of lymphocytes in places separates the tumour cells from thyroid tissue (Fig. 4).

The histological diagnosis is reticulum cell sarcoma and possibly pre-existent thyroiditis.

CASE 3 (No. 12106) Mrs. C. C., aged 67 years, was first seen in December 1959 with a complaint of 'tightness' in the neck of 12 months' duration, and rapid enlargement of the left lobe of the thyroid for six weeks, associated with dyspnoea. Examination revealed enlargement of both lobes of the thyroid, particularly the left, which was hard and fixed. An enlarged lymph node was present behind the sternomastoid. Radiological examination showed tracheal deviation to the right. Bronchoscopy showed no infiltration.

At operation in December 1959 the thyroid was diffusely enlarged and formed a large fleshy, neoplastic-

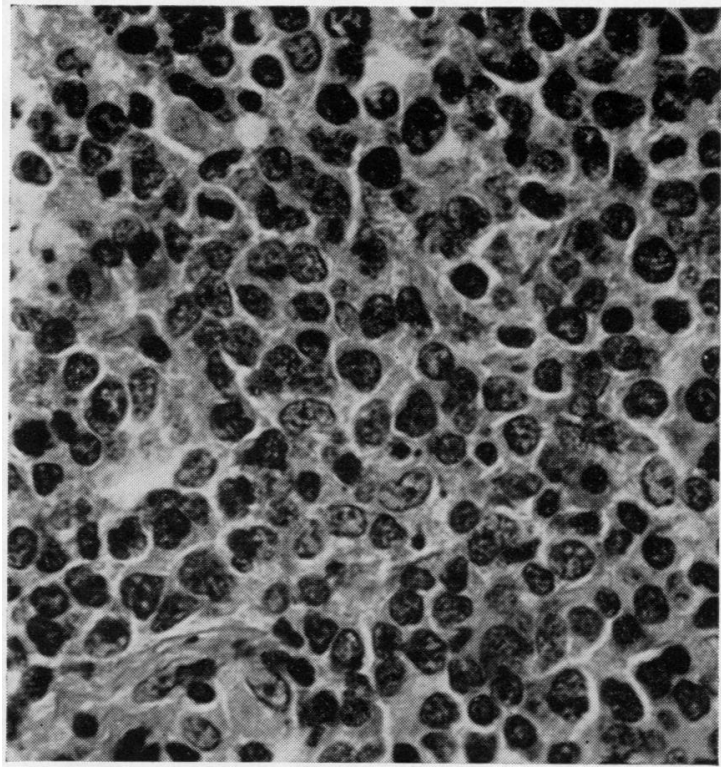

FIG. 3. Case 2: reticulum cell sarcoma. Haematoxylin and eosin $\times 450$.

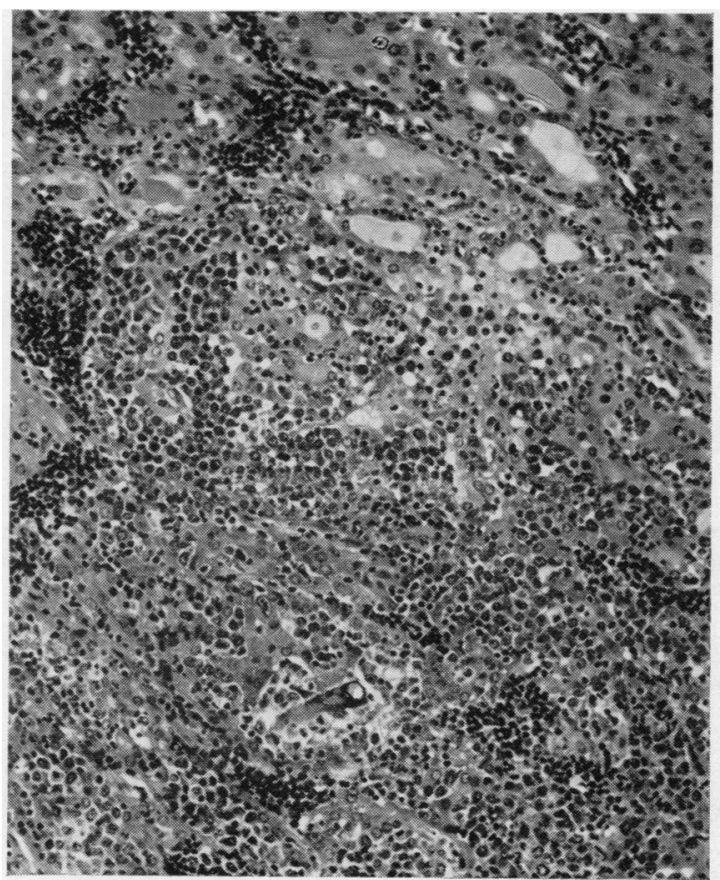

FIG. 4. Case 2: an incomplete halo of lymphocytes at the advancing tumour margin. Haematoxylin and eosin $\times 110$. 
looking mass which was not disturbed. A large fleshy lymph node was removed from the right posterior triangle.

Radiotherapy in a radical dosage was given postoperatively and complete resolution occurred, apart from a small nodule in the operation scar; this regressed with a second dose of radiotherapy. There was no subsequent evidence of recurrence locally or of generalized disease, when the patient was last seen in August 1963.

The histological appearance of the lymph node was of complete replacement by cells of reticulum and lymphoblastic type, infiltrating the capsule and adjacent fat.

The presumptive diagnosis was reticulum cell sarcoma of the thyroid with lymph node involvement.

CASE 4 Mrs. B. G., aged 60 years, was first seen in October 1961 when she complained of swelling of the right side of neck and of dysphagia of one month's duration. There was no evidence of generalized disease. The liver and spleen were impalpable.

At operation in December 1961 the thyroid was seen to be markedly enlarged, particularly the left lobe, with retrosternal extension. Hemithyroidectomy was attempted but was impossible because of infiltration of the trachea. Lymph nodes were not enlarged.

Radiotherapy was given post-operatively in radical dosage and the mass regressed completely. She remained well for 14 months when she complained of left-sided abdominal pain, and examination showed marked splenomegaly. Local radiotherapy resulted in regression, but two months later lymph nodes were enlarged in the left axilla and right groin, and in September 1962 the liver was enlarged and a mass of tumour was present in the right biceps. She died in October 1962. No necropsy was performed.

Histology (2302/62) A lobular pattern is present, the gland being incompletely divided by strands of fibrous tissue. The tumour tissue presents sheets of cells, mature lymphocytes, lymphoblasts, and a few reticulum cells. Islands of thyroid epithelium lying within the tumour tissue show Askanazy change but no tumour-free tissue is available to examine for evidence of pre-existent thyroid disease.

The diagnosis is lymphocytic lymphosarcoma, possibly of systemic type.

CASE 5 (No. 127954) Mrs. M. S., aged 68 years, was transferred from another hospital in January 1960 with a history of thyroid swelling, of unrecorded duration, associated with bilateral cervical lymphadenopathy, dyspnoea, stridor, and orthopnoea.

Examination showed a grossly enlarged thyroid and cervical lymph nodes, and marked venous congestion of the face and neck. The clinical diagnosis was carcinoma of the thyroid. Laryngoscopy was technically unsatisfactory. Radiographic examination showed tracheal displacement and compression. Thyroid antibody tests proved significantly positive.

Operation showed gross enlargement of the entire gland, the left lobe being 10 times larger than normal. There was retropharyngeal extension with infiltration of strap muscles, the trachea, and cricoid structures. Wedge resection only was possible, and paralysis of the left recurrent laryngeal nerve was noted post-operatively.

Radiotherapy was given in February 1961 in a radica ? dosage, and resulted in regression of the thyroid swelling but not of the lymph nodes. A course of cyclophosphㅡㅡㅁ amide in April 1961 resulted in regression of the enlargect lymph nodes.

In August 1961 profound weakness, weight loss, and్ anaemia were treated with blood transfusion and anabolics steroids with good symptomatic effect. There was no evidence of local or general recurrence at that time $\vec{Z}$ Shortly afterwards a large mass appeared subcutaneously in the left subclavicular region with a tender nodulat. expansion over the sternum and second rib. A furthe course of cyclophosphamide again resulted in some regression. Twelve months after her first attendance a swelling appeared in the posterior third of the tongues with the clinical appearance of lymphosarcoma. The patient refused further treatment in hospital and died a? home 12 months after she was first seen.

Histology $(871 / 61)$ A wedge resection removed $\vec{b}$ thyroid tissue weighing $12 \mathrm{~g}$. A frozen section suggested plasmacytoma because of the predominance of plasma myeloma-like cells. Paraffin sections from areas of tumour free tissue show a lobular pattern with the picture o® Hashimoto thyroiditis, namely germinal follicles, Askanazy change, lymphocytic infiltration, and fibrosis (Fig. 5) other sections show a completely different picture with ${ }^{\circledR}$ sheets of tumour cells, predominantly reticulum cells? lymphoblasts, and large abnormal cells, many with char acters transitional between reticulum cells and myelomo like cells (as observed by Parsons (1943) in the lymph nodes of tumour-bearing mice) replacing thyroid tissu亳 (Fig. 6). Capsular and fatty infiltration outside the gland is evident. In other areas sheets of tumour cells are seer $\overrightarrow{\vec{\sigma}}$ sweeping between remnants of thyroid acini, the epi 3 thelium of which shows marked Askanazy change. The lobular pattern is maintained in some places, fibrosis iso abundant, and the elaboration of reticulin eviden (Fig. 7). The histological diagnosis is reticulum celf sarcoma associated with Hashimoto's thyroiditis.

CASE 6 (No. 132561) Mrs. E. M., aged 83 years, waß̊ seen in January 1962 complaining of swelling of the neck for one month, associated with hoarseness, dysphagiao and intermittent stridor. Examination revealed diffuse enlargement of the thyroid which was hard and irregular No cervical lymphadenopathy was found. Radiographic. examination showed tracheal displacement to the right $N$ Radioactive iodine uptake was diminished in the left lobe. Thyroid antibody tests proved negative, and laryn goscopy showed a fixed, paralysed cord and a large smooth swelling bulging the left side of the pharynx.

At operation the left lobe of the thyroid was enlarge to eight times normal size and extended behind the larynx and into the superior mediastinum. The right lobe wa\& enlarged three times normal size. The gland was soft: fleshy, and friable; the pharynx and trachea were infiltrated and the lymph nodes in the anterior triangle were enlarged. Total thyroidectomy was carried out.

Radiotherapy was not given because of the patient' age and the relatively good prognosis claimed for similat 


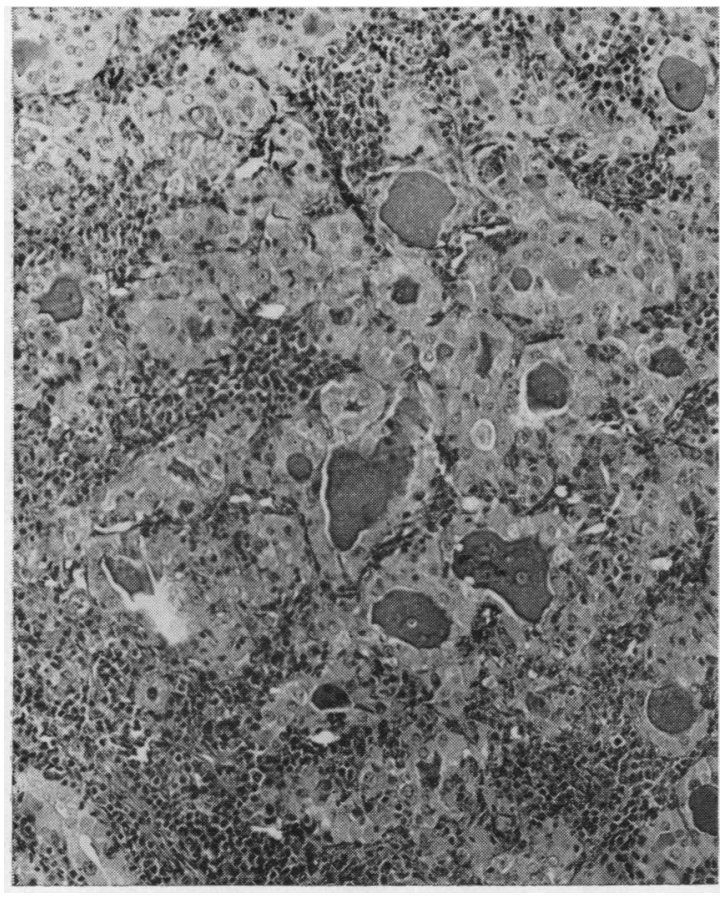

FIG. 5. Case 5: florid thyroiditis from an area of Hashimoto pattern. Haematoyxlin and eosin $\times 110$.

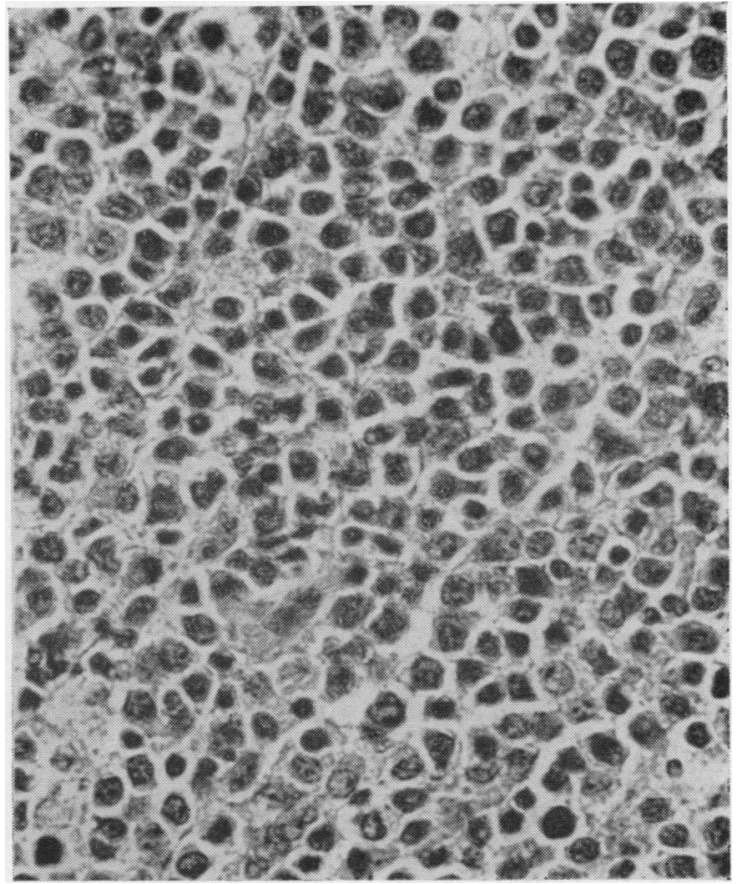

FIG. 6. Case 5: reticulum cells, lymphoblasts, and myeloma plasma cells. Haematoxylin and eosin $\times 450$.

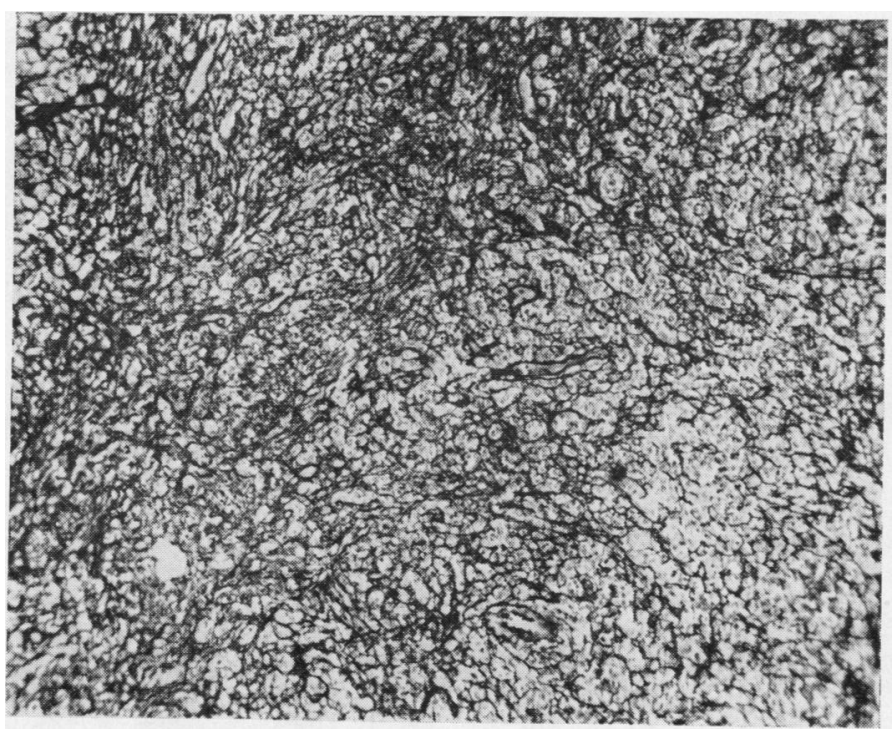

FIG. 7. Case 5: reticulum proliferation within tumour tissue. 


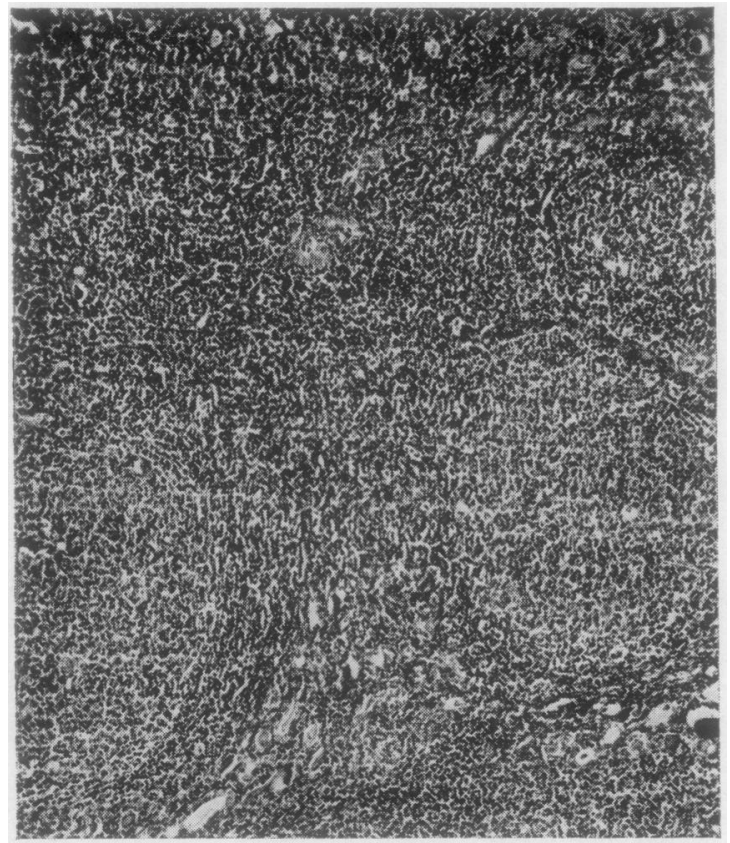

FIG. 8. Case 6: giant abnormal lymphoid follicles reminiscent of follicular lymphoma. Haematoxylin and eosin $\times 4$.

lesions. She was seen eight months later complaining of severe dizziness and episodes of loss of consciousness; she believed she had had a single epileptiform fit. Her legs were weak and she had fallen several times. There was a sensation of fullness with pressure over the left fronto-parietal region, though no headaches. No focal signs in the central nervous system were elicited. She collapsed and died a week later at home. No necropsy was permitted.

The patient survived 11 months from the onset and 10 months from operation.

Histology $(1979 / 62)$ The gland weighed $208 \mathrm{~g}$. Striated muscle and the capsule of the thyroid are infiltrated by sheets of tumour tissue composed of reticulum cells of bizarre form and lymphoblasts. Mitoses are frequent. The neoplastic cells are sweeping between thyroid acini leaving intact colloid-containing follicles in some areas but infiltrating the follicles in others. There is no evidence of thyroiditis either within the tumour tissue or at its margins. Some giant lymphoid follicles are seen which appear abnormal (Fig. 8); in one area a gradation appears to have occurred between such a follicle and the tumour tissue. The appearances are those of reticulum cell sarcoma with a somewhat follicular pattern, in part reminiscent of Brill-Symmers disease.

CASE 7 (No. 132437) Mrs. C. D., aged 59 years, was first seen in January 1962 complaining of swelling of the neck for three months. She had no previous goitre. Examination revealed enlargement of the thyroid three times normal size with a large nodular mass in the right lobe. $\stackrel{-}{*}$ Radiographic examination showed tracheal displacement to the left; laryngoscopy showed no abnormality, radioactive iodine uptake was diminished in the right lobe, and thyroid antibody tests were of doubtful significance.

At operation the right lobe, isthmus, and part of the $\frac{\sigma}{\vec{\gamma}}$ left lobe were involved by a fleshy nodular mass, adherento to the deep aspect of the strap muscles. No gross lymph node enlargement was noted but two pretracheal nodeswere removed. Subtotal thyroidectomy was followed by. normal convalescence.

A full course of radiotherapy was given within the next month, and four months later no recurrence was evident. In October 1962 she was admitted to hospital? with dysphagia, vomiting, and cervical pain. An oeso $-\vec{V}$ phageal stricture at $13 \mathrm{~cm}$. was found and dilated. Anos oesophago-tracheal fistula resulted, and a torrentialor haemorrhage produced fatal collapse. Necropsy showed erosion of the right subclavian artery within a mass of음 fibrotic, haemorrhagic tissue. There was no evidence of local recurrence or metastatic spread and no generalizedZ involvement of lymphatic tissue.

Histology (2091/62) The left lobe weighed 5 g. and $\frac{\Phi}{3}$ the right lobe $84 \mathrm{~g}$.

Macroscopically the cut surface shows a lobular文 pattern due to fibrous trabeculation. The tumour is $\overrightarrow{0}$ composed predominantly of reticulum cells which show moderate pleomorphism, and occasional bizarre multi- $\$$ nucleate forms and moderately frequent mitoses. Invasion? of muscle (Fig. 9), capsule, and blood vessels by tumour is noted, but in other areas blood vessels are packed with mature lymphocytes which are not obviously neoplastion (Fig. 10). Thyroid epithelium of normal appearance with no Askanazy change is seen within the tumour, and at the margins in most sections. In one area, however, there areō some large lymphoid follicles lying between norma $\beta$ thyroid tissue, the appearance being reminiscent of benign follicular lymphoma and transition between one such area and tumour tissue is suggested. The advancing edge of tumour tissue is one area is associated witho Askanazy change in adjacent epithelium. The lymph nodes showed no involvement with reticulum celp sarcoma but macrophage proliferation is marked in sinuses. The appearances are those of reticulum celB sarcoma. There is no evidence of Hashimoto's thyroiditis but Askanazy change in relation to an area of tumour tissue is noted.

CASE 8 (No. 133863) Mrs. M. C., aged 53 years, was firs seen in April 1962 complaining of swelling of the neck for 12 months with recent increase in size associate with dyspnoea, orthopnoea, and stridor, especially at night. A year previously she had been investigated fo 'gastro-enteritis' for which no cause was found. Profound lassitude had been present for several months. Examin ation revealed a hard mass in the right lobe of thyroids which was displacing the trachea and producing venous congestion of the neck and upper chest wall.

Radiographic examination showed tracheal displace $\frac{\vec{\Phi}}{\Phi}$ ment to the left. Uptake of radioactive iodine in the righ? lobe of the thyroid was diminished; thyroid antibod 8 tests were possibly significant. 


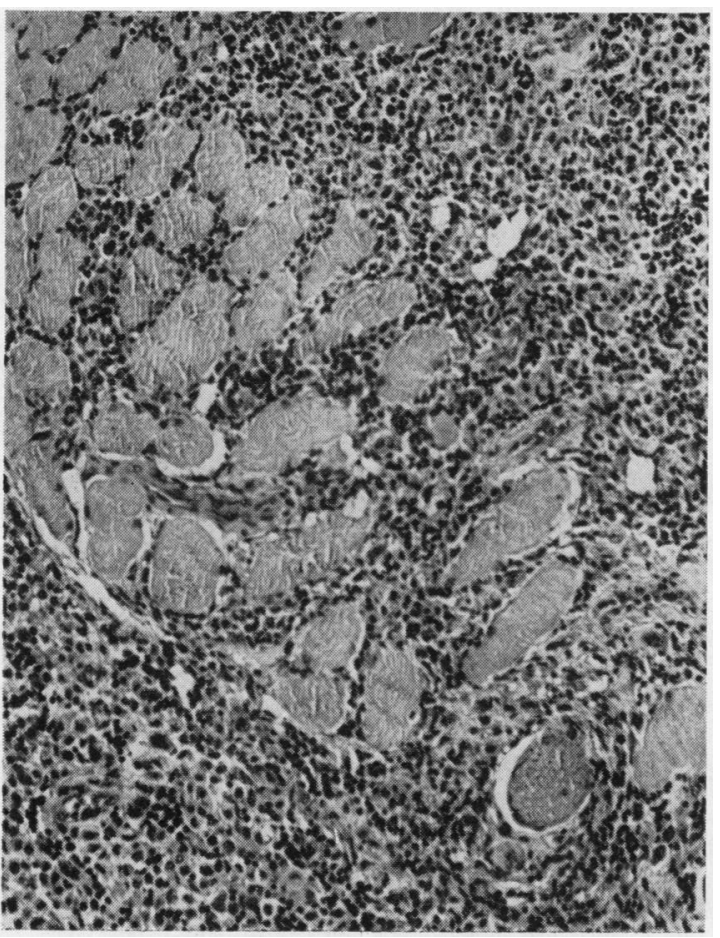

FIG. 9. Case 7: muscle infiltrated by tumour. Haematoxylin and eosin $\times 110$.

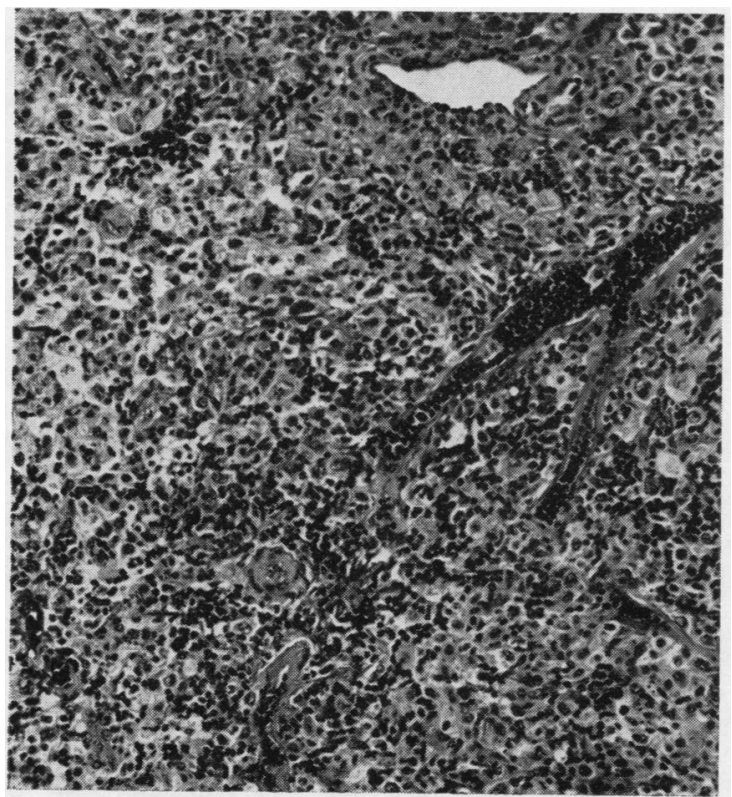

FIG. 10. Case 7: mature lymphocytes packing a vessel within tumour. Haematoxylin and eosin $\times 110$.
At operation the right lobe of the thyroid was enlarged and of soft, fleshy consistency. The left lobe was similar but smaller than normal with a nodule in the lower pole. Total thyroidectomy was performed and a lymph node excised from the region of the jugular vein. There had been no recurrence in July 1963.

Histology (2257/62) The gland weighed 60 g. A distinctly lobulated pattern is seen macroscopically.

One area shows a particularly florid thyroiditis with extensive disruption of acini with Askanazy change and marked fibrosis and lymphocytic infiltration but without germinal follicles. In other areas, although the lobular pattern is retained, lymphocytic infiltration is replaced by sheets of tumour tissue mainly of lymphoblastic type, but with some more mature lymphocytes. The actual transition from a benign to a neoplastic condition is very difficult to define. The appearances are those of lymphoblastic lymphosarcoma with evidence of thyroiditis, almost certainly pre-existent.

CASE 9 Mrs. D. T., aged 39 years, was first seen in January 1962 when she complained of swelling of the neck for three months. It had first manifested itself as a rapid nodular enlargement of the right lobe of the thyroid associated with 'influenzal symptoms'. The swelling had regressed in two weeks, but a diffuse swelling of thyroid followed a month later and rapidly progressed to massive proportions. There was associated local tenderness, dyspnoea, and orthopnoea. Two weeks before consultation she had epigastric pain, nausea, and vomiting, flatulent dyspepsia, diarrhoea, and jaundice. Examination showed an icteric woman in fair general health. The thyroid enlargement presented three nodular masses which appeared to involve the whole gland. There was no hepatosplenomegaly or lymphadenopathy.

Investigations demonstrated obstructive jaundice, and a barium meal showed indentation of the duodenum by a mass which was thought to be located in the head of the pancreas. Thyroid antibody tests were negative. The provisional diagnosis was sarcoma of the thyroid with gastrointestinal metastases.

Operation on the neck became imperative to relieve respiratory distress and laparotomy was undertaken simultaneously. The whole of the thyroid was replaced by yellowish, firm tissue tumour. Wedge resections of the central and lateral masses were carried out. Laparotomy showed a diffuse, yellowish nodular tumour mass in the head and body of the pancreas obstructing the common bile duct and the duodenum. The jejunum contained similar masses involving the whole circumference of the wall and mesenteric lymph nodes were enlarged. Biopsies were taken of the jejunum and a lymph node; cholecystjejunostomy was carried out.

After a stormy post-operative course, complicated by biliary peritonitis and pelvic abscess, the patient died in April 1962.

Necropsy revealed extensive bronchopneumonia but no mediastinal adenopathy. The first and second parts of the duodenum were extensively infiltrated by tumour tissue lying deep to an intact mucosa except at one point where ulceration had occurred. The tumour was obstructing the common bile duct and fixed in the region of the 
head of the pancreas. which was also replaced by a large tumour mass. A kidney contained several nodules of tumour from 1 to $3 \mathrm{~cm}$. in diameter. The liver showed extensive, severe fatty infiltration but no secondary deposits. The spleen appeared normal. Thyroid remnants contained tumour cells infiltrating local tissue. Cervical lymphadenopathy was marked.

Histology The thyroid parenchyma is replaced by sheets of tumour tissue of reticulum cell and lymphoblastic type in varying proportions in different areas. Islands of normal acini are present, others are invaginated by tumour cells (Fig. 11). No thyroiditis is evident. There are foci of haemorrhage and necrosis. Examination of specimens obtained at necropsy show tumour tissue similar in appearance to the thyroid tumour.

\section{DISCUSSION}

The nine cases designated malignant lymphoma of the thyroid have presented many of the features previously recorded in the literature. Eight of the patients were elderly; all were women. A fairly constant clinical picture was presented, namely, rapid enlargement of the neck, often markedly unilateral, in a thyroid gland which, in three cases, had previously presented a goitre, and in six which had not. The duration of goitre before the onset of acute symptoms may be of importance in discussing the role of Hashimoto thyroiditis as an antecedent condition. In none of our cases was the malignant nature of the condition clinically in doubt, eight being diagnosed pre-operatively as carcinoma and one as sarcoma. In all cases in which the test was carried out, the radio-active iodine uptake supported the diagnosis of malignant disease, the areas of defective uptake correlating with the anatomical

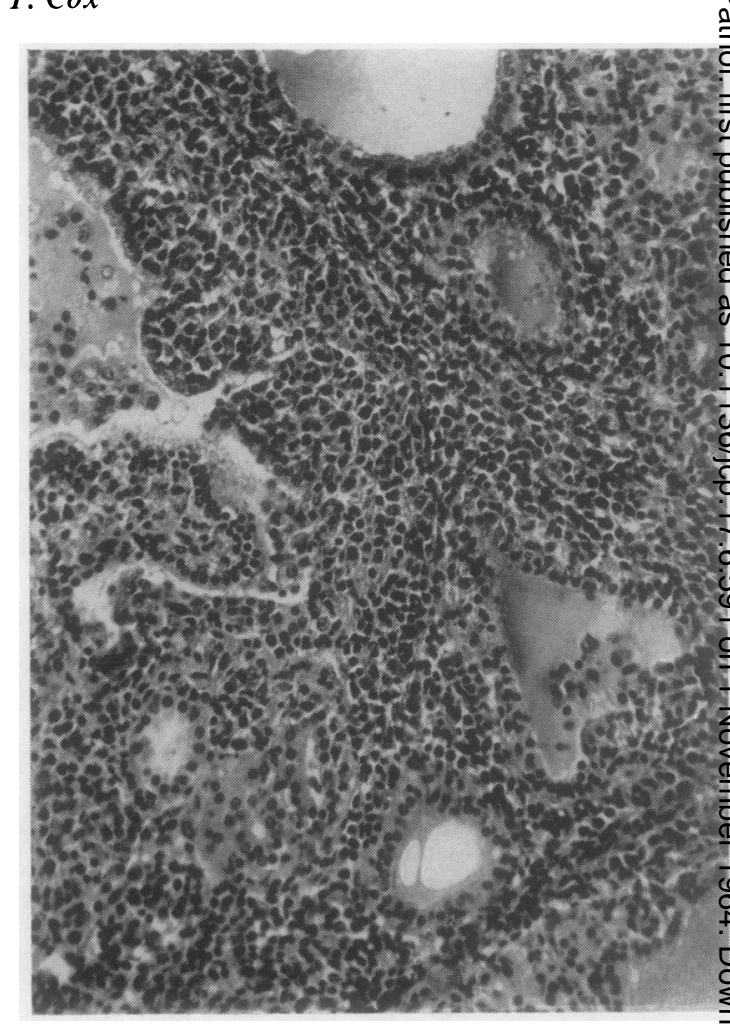

FIG. 11. Case 9: tumour infiltrating between and invag $\bar{\emptyset}$

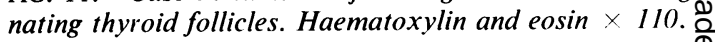

tumour. The blood picture was normal initially and at no time did a leukaemoid picture develop. Thyroid antibody tests were carried out in six casef

TABLE I

THE PRINCIPAL FEATURES IN NINE CASES OF MALIGNANT LYMPHOMA OF THE THYROID GLAND

\begin{tabular}{|c|c|c|c|c|c|c|c|c|c|}
\hline \multirow{2}{*}{$\begin{array}{l}\text { Case } \\
\text { No. }\end{array}$} & \multirow{2}{*}{$\begin{array}{l}\text { Age } \\
(y r .)\end{array}$} & \multirow[t]{2}{*}{ Goitre } & \multirow{2}{*}{$\begin{array}{l}\text { Duration of } \\
\text { Acute } \\
\text { Symptoms }\end{array}$} & \multirow[t]{2}{*}{ Histology } & \multirow{2}{*}{$\begin{array}{l}\text { Extrathyroid } \\
\text { Involvement }\end{array}$} & \multirow[t]{2}{*}{ Thyroiditis } & \multirow[t]{2}{*}{ Serology } & \multicolumn{2}{|l|}{ Survival } \\
\hline & & & & & & & & Onset & Operatio \\
\hline DT 1 & 72 & $12 \mathrm{mth}$ & $2 \mathrm{mth}$. & $\begin{array}{l}\text { Reticulum cell } \\
\text { sarcoma }\end{array}$ & Inguinal lymph-nodes & No & Not done & $39 \mathrm{mth}$. & $27 \mathrm{mth}$. \\
\hline BH 2 & 68 & - & $1 \mathrm{mth}$ & $\begin{array}{l}\text { Reticulum cell } \\
\text { sarcoma }\end{array}$ & - & Possible & Not done & $4 \mathrm{mth}$ & $3 \mathrm{mth}$. \\
\hline $\mathrm{CC} 3$ & 67 & $12 \mathrm{mth}$. & $6 \mathrm{wk}$. & $\begin{array}{l}\text { ? Reticulum cell } \\
\text { sarcoma }\end{array}$ & Cervical lymph-nodes & - & Not done & $45 \mathrm{mth}$. & $\begin{array}{l}43 \mathrm{mth} \text {. } \\
\text { (alive and } \\
\text { well) }\end{array}$ \\
\hline BG 4 & 60 & No & $1 \mathrm{mth}$. & $\begin{array}{l}\text { Lymphocytic } \\
\text { lymphosarcoma }\end{array}$ & $\begin{array}{l}\text { Lymph-nodes, spleen, } \\
\text { liver, muscle }\end{array}$ & $\begin{array}{l}\text { Insufficient } \\
\text { evidence }\end{array}$ & -- & $13 \mathrm{mth}$ & $1 \mathrm{yr}$. \\
\hline MS 5 & 68 & $\begin{array}{l}\text { Not } \\
\text { known }\end{array}$ & Not known & $\begin{array}{l}\text { Reticulum cell } \\
\text { sarcoma }\end{array}$ & $\begin{array}{l}\text { Cervical nodes, skin, } \\
\text { sternum, ribs, tongue }\end{array}$ & Yes & Significant & $1 \mathrm{yr}$ & $11 \mathrm{mth}$ \\
\hline EM 6 & 83 & No & $1 \mathrm{mth}$ & $\begin{array}{l}\text { Reticulum cell } \\
\text { sarcoma }\end{array}$ & ? Intracranial & No & Negative & $11 \mathrm{mth}$ & $10 \mathrm{mth} . \mathrm{c}$ \\
\hline CD 7 & 59 & No & $3 \mathrm{mth}$. & $\begin{array}{l}\text { Reticulum cell } \\
\text { sarcoma }\end{array}$ & None & No & Doubtful & $13 \mathrm{~min}$. & $10 \mathrm{mth}$. \\
\hline MC 8 & 53 & $12 \mathrm{mth}$. & $6 \mathrm{wk}$. & $\begin{array}{l}\text { Lymphoblastic } \\
\text { lymphosarcoma }\end{array}$ & - & Yes & $\begin{array}{l}\text { Possibly } \\
\text { significant }\end{array}$ & $28 \mathrm{mth}$. & $\begin{array}{l}16 \mathrm{mth} . \\
\text { (alive an } \\
\text { well) }\end{array}$ \\
\hline DT 9 & 39 & $3 \mathrm{mth}$. & $6 \mathrm{wk}$ & $\begin{array}{l}\text { Lymphoblastic } \\
\text { lymphosarcoma }\end{array}$ & $\begin{array}{l}\text { Cervical lymph nodes, } \\
\text { jejunum, kidneys, } \\
\text { pancreas }\end{array}$ & Yes & Negative & $7 \mathrm{mth}$ & $3 \mathrm{mth}$. \\
\hline
\end{tabular}


pre-operatively. The results of other investigations are not recorded as they did not appear significant.

HISTOLOGICAL FEATURES In examining the histological specimens the following points were taken into account: the predominant cell type, demonstration of its malignant propensity, examination of material free from tumour for evidence of co-existent thyroid disease, and the possible demonstration of a transition from pre-existent disease to neoplasia.

The tumour can be classified as reticulum cell sarcoma or immature lymphosarcoma showing the features of these conditions as they occur in other organs, and certain appearances were common to all. Under low-power magnification they show a monotonous picture-sheets of tumour cells replacing the normal thyroid architecture, leaving isolated foci of thyroid acini, some of which show no changes (case 1) and others marked Askanazy change. The neoplastic cells have a predilection for infiltration of follicles (Figs. 1 and 2), blood vessels, and lymphatics. In places the tumour tissue is separated from adjacent thyroid epithelium by a halo of lymphocytes without abnormal characters. Similar lymphocytes are seen packing blood vessels within the tumour (Fig. 10).

Extension beyond the gland, through the capsule and trabeculae, with infiltration of muscle and fat, is frequent. The presence within the tumour tissue of cells showing a bizarre configuration, hyperchromatism, multinuclear forms, and mitotic figures lends support to the view that this is a neoplastic rather than a granulomatous condition-a malignant lymphomatous neoplasia rather than a 'struma reticulosa'.

RELATIONSHIP OF MALIGNANT LYMPHOMA OF THE THYROID TO HASHIMOTO THYROIDITIS This has been a subject of discussion for some time, and in a search for a possible relationship between these two conditions the histological specimens were examined without knowledge of the prior existence of a goitre or the results of the serological tests.

It was considered that some confusion in the past may have resulted from failure to accept rigid criteria for the histological diagnosis of struma lymphomatosa and therefore the criteria used by Walt et al. (1957) were employed. These include lymphocytic infiltration, Askanazy change in the thyroid epithelium, the presence of germinal follicles and fibrosis, all occurring in varying proportion although not necessarily together, in areas of the gland free from tumour. The difficulties involved in the histological diagnosis of struma lymphomatosa have been further discussed by Woolner et al. (1959). Obviously it is not possible to assess accurately the diffuseness of the thyroiditis because large tracts of the gland have been altered by the neoplastic process. Areas showing some, but not all, of the features of Hashimoto's struma have been termed 'thyroiditis'.

In case 1 several areas were available free from tumour tissue but no evidence of Hashimoto thyroiditis was present. Irrefutable evidence was exhibited by only two specimens, namely, cases 5 and 8, the remainder showing varying degrees of fibrosis, lymphocytic infiltration, and Askanazy change. This last was seen within tumour tissue, at its margins, and in unaffected thyroid epithelium. The presence of normal thyroid epithelium in relation to tumour tissue in cases 1 and 6 suggests that the change is not necessarily induced by the neoplastic cells. The distribution of the degenerative eosinophilic changes in the glandular epithelium in areas of tumour and tumour-free tissue in the same organ supports the suggestion that the neoplastic cells arise from lymphoid tissue already present as part of thyroiditis which has itself induced degenerative changes in the epithelium. It is tempting to suggest disruption of the lymphoid follicles by the progressive neoplastic process to account for the absence of lymphoid follicles in those cases of 'thyroiditis' where they are not a feature of the microscopic picture (Kenyon and Ackerman, 1955).

In reviewing 78 cases from the literature, Roberts (1961) found that a definite association between Hashimoto thyroiditis and malignant lymphoma had been claimed in a third and discounted in a third of these cases; in the remainder it was not discussed, in some instances inadequate material being available for such an assessment.

Adopting similar criteria, Walt and his colleagues found an association in only three of their 21 cases of lymphosarcoma, and Dinsmore, Dempsey, and Hazard (1949) in one of eight cases. Kellett and Sutherland (1949) recorded lymphoid hyperplasia in three of four cases but did not regard it as proof of Hashimoto thyroiditis: Lindsay and Dailey (1955) found a struma lymphomatosa in seven of their eight cases and regarded it as significant; similarly Rangström (1957) noted it in seven cases, four of which were undoubtedly malignant, and Welch et al. in two of their four cases. Woolner and his co-authors (1959) noted 12 cases of lymphosarcoma and 605 cases of struma lymphomatosa, three of the former showing diffuse thyroiditis in extratumerous tissue, focal changes only being present in the remainder.

The most convincing evidence of Hashimoto thyroiditis preceding malignant lymphoma has been provided by Cureton, Harland, Hosford, and Pike (1957), and appears irrefutable, their case 1 
having typical Hashimoto thyroiditis in the lateral lobes of the gland and a reticulo-sarcoma developing in nodular form in the isthmus, and case 2 showing the progression of a reticulo-sarcoma over two years in a gland initially showing large areas of Hashimoto thyroiditis. Ultimately the neoplastic tissue may obliterate the evidence of the pre-existent thyroiditis. Kenyon and Ackerman (1955) claimed a similar association, one of their cases being myxoedematous before neoplastic transition. In the cases of lymphosarcoma of Metcalfe and Sclare (1961) three arose in diffuse chronic thyroiditis, one in myxoedema, and one in focal thyroiditis. Crile and Hazard (1962), reported the development of reticulum cell sarcoma in a case of struma lymphomatosa diagnosed by biopsy and under treatment. It is generally accepted that malignant lymphoma of the thyroid is frequently associated with lymphoid infiltration or hyperplasia and in some cases the lymphoid tissue is an integral part of Hashimoto thyroiditis. That it can occur in the absence of thyroiditis is demonstrated in two of our cases, in which thyroiditis does not exist and is not induced secondarily by the tumour.

SEROLOGICAL TESTS In a discussion of the condition of malignant lymphoma in 1960 Doniach suggested that recent advances in technique for the demonstration of thyroid antibodies might prove of value in these cases. Where serum was available these tests were carried out and the results are recorded in Table II.

The techniques used were the thyroid precipitin test using the modified Oudin gel diffusion method, tanned red cell agglutination (Fulthorpe, Roitt, Doniach, and Couchman, 1961), the complementfixation test (Roitt and Doniach, 1958), and the fluorescent method for thyroglobulin and cystoplasmic antibodies and antinuclear factors.

The value of these tests in the diagnosis of Hashimoto thyroiditis is well established. In cases reviewed by Doniach (1960) and by Evans (1962), 90\% of histologically proven cases have significant titres of antibodies assessed by the tanned red cell, complement-fixation, and precipitin tests. The majority of the remainder have been shown to have antibodies to the second colloid antigen $\mathrm{CA}_{2}$ by the fluorescent $\stackrel{\circ}{-}$ technique (Balfour, Doniach, Roitt, and Couch- $\stackrel{\vec{D}}{\vec{P}}$ man, 1961).

In discussing these tests Doniach stated that a positive precipitin test indicates a widespread $\overline{\bar{\omega}}$. 'thyroiditis'. During investigation of 303 cases of $\overrightarrow{\mathrm{D}}$ lymphadenoid goitre she found a tanned red cell titre of $1 / 25,000$ in $84 \%$, two-thirds of which had ${ }^{\infty}$ also positive precipitin and a complement-fixation $\vec{O}$

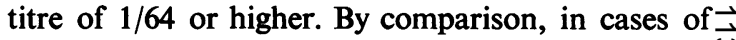
cancer of the thyroid Doniach et al. (1958) found that ${ }_{\sigma}^{\omega}$ $71 \%$ had negative serological tests, $16 \%$ low, and $13 \%$ moderate titres. It was thought that these tests? were of some value in differentiation of thyroiditis. $\vec{v}$ from cancer of the thyroid when taken in association os with the clinical features. Stewart and Allen (1958), however, found raised tanned red cell titres in three $\mathrm{O}$ of six cases of thyroid cancer two of which had positive precipitin tests.

The value of such tests in a large number of cases? of malignant lymphoma has not been recorded though (Roitt and Doniach, 1958) quote high titres of antibodies in a case of lymphosarcoma arising in a Hashimoto goitre. Our own cases obviously form $\vec{\varphi}$ too small a series to be of statistical value. It is signi- + ficant, however, that raised titres, in the Hashimoto thyroiditis range, were present in cases 5 and 8 , in which there was undoubted histological evidence of this process, and therefore it is considered that this is its only value. Where significant titres are $\frac{0}{D}$

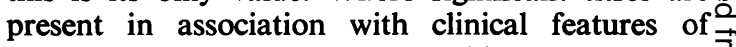
malignancy, it may be reasonable to suspect a윽 sarcomatous rather than a carcinomatous process $\frac{?}{?}$ but absence of thyroid antibodies does not in any way invalidate the diagnosis of the former condition, (cases 6 and 9). Essentially the results indicate a응 concomitant or pre-existent thyroiditis; their relation- - ship to the neoplastic process itself remains undetermined.

DISTRIBUTION OF METASTASES When necropsieso have been carried out an unusual distribution of metastases has been observed in the majority of cases of malignant lymphoma of the thyroid. This is of interest in relation to the aetiology of the o condition, and occasionally of value in accounting $\tilde{O}$

TABLE II

RESULTS OF SEROLOGICAL TESTS

\begin{tabular}{|c|c|c|c|c|c|c|}
\hline \multirow{3}{*}{ Case No. } & \multirow{3}{*}{ Precipitin } & \multirow{3}{*}{ Tanned Red Cell } & \multirow{3}{*}{$\begin{array}{l}\text { Complement } \\
\text { Fixation }\end{array}$} & \multirow{2}{*}{\multicolumn{3}{|c|}{ Coons Fluorescent Technique }} \\
\hline & & & & & & \\
\hline & & & & Colloid & Cytoplasmic & Antinuclear Factors \\
\hline $\begin{array}{l}4 \\
5 \\
6 \\
7 \\
8 \\
9\end{array}$ & $\begin{array}{l}\text { Negative } \\
\text { Positive } \\
\text { Negative } \\
\text { Negative } \\
\text { Negative } \\
\text { Negative }\end{array}$ & $\begin{array}{l}-\overline{1 / 2,500,000} \\
1 / 250 \\
1 / 2,500 \\
1 / 25,000 \\
1 / 24\end{array}$ & $\begin{array}{l}1 / 8 \\
1 / 32 \\
\text { Negative } \\
\text { Negative } \\
\text { Negative } \\
\text { Negative }\end{array}$ & $\begin{array}{l}+ \\
+++ \\
\text { Negative } \\
+ \\
+ \\
+\end{array}$ & $\begin{array}{l}+ \\
+ \\
\text { Negative } \\
+ \\
\text { Negative } \\
+\end{array}$ & $\begin{array}{l}\text { Negative } \\
\text { Negative } \\
\text { Negative } \\
\text { Negative } \\
\text { Negative } \\
\text { Negative }\end{array}$ \\
\hline
\end{tabular}


for the unusual clinical features which may be present and in distinguishing the condition clinically from carcinoma of thyroid. A peculiar proclivity for the gastrointestinal tract is evident, though widespread dissemination does occur. Brewer and Orr (1953), noting this association, recorded jejunal deposits in two of their own cases and quoted a case with deposits in the cervical glands, stomach, intestine, kidney, and vertebral bodies, and another with multiple intestinal deposits. Involvement of the jejunum and cervical lymph nodes in one case and retrosternal and retroperitoneal lymph nodes, stomach, ileum and rectal involvement in another case was recorded by Dick and Kellett (1951). Scott (1952) noted a tumour in the kidney, and deposits in the stomach and tracheo-bronchial tissue in two patients respectively. Metastases in liver, lymph nodes, suprarenals, kidneys, ovaries, and pancreas were described by Welch et al. (1958) and a deposit in breast tissue by Winship and Greene (1955) in a woman suspected of having multiple secondaries, and in the lung, pericardium, and pancreas in another of their cases. A single large liver tumour associated with thyroid lymphoma was recorded by Conklin and Gent (1957) and small intestinal deposits by Metcalfe and Sclare (1961).

The present series is deficient in that necropsy material is available in only two cases, but again a slightly unusual metastatic distribution is noted. Not surprising is the frequent involvement of lymphatic glands in the drainage areas in the neck; this was noted in five cases. Uncommon is the dissemination to skin, bone, and tongue in case 5 , but the distribution in case 9 to lymph nodes, gastrointestinal tract, pancreas, and kidneys is in keeping with the findings in other series. Case 4 is unusual, showing involvement of multiple lymph nodes, liver, and spleen, a feature more in keeping with systemic malignant lymphomata, and suggesting the possiblity of a multifocal origin with simultaneous involvement of the thyroid. However, the time interval and the serological evidence of preceding pathological changes in the gland may justify its inclusion in the group of primary lymphoma of thyroid on the present evidence. Case 7 illustrates well the primary origin in the thyroid gland.

The variable prognosis in this condition has been noted in many series and, together with certain histological features, prompted Brewer and Orr (1953) to put forward the term 'struma reticulosa' as being more suitable than others which imply a proven malignant transformation. It is not intended to discuss this further, since in the present cases the histological features are those of malignancy as accepted in other situations. However, it has not been possible to distinguish histologically, even in retrospect, between those cases in which death occurred within a very short time and those which have survived longer, the prognosis being generally poor (see Table I).

I should like to thank the medical staff of the Thyroid Clinic at the David Lewis Northern Hospital, Liverpool, for access to their clinical records, and particularly $\mathrm{Mr}$. Philip Hawe for his interest and encouragement. I am indebted to Dr. R. Winston Evans for constant guidance and help and to Miss C. McDougall for technical assistance.

Access to other records was given by courtesy of Mr. David Annis, Liverpool Royal Infirmary, Mr. W. R. Hunter, Ormskirk County Hospital, and Mr. A. W. B. Strachan, of the North Lonsdale Hospital, Barrow in Furness. The serological tests were carried out by Dr. Deborah Doniach at the Middlesex Hospital, London, to whom I offer my thanks.

\section{REFERENCES}

Balfour, B. M., Doniach, D., Roitt, I. M., and Couchman, K. G. (1961). Brit. J. exp. Path., 42, 307.

Brewer, D. B., and Orr, J. W. (1953). J. Path. Bact., 6, 193.

Conklin, S. D., and Gent, D. H. (1957). Ann. intern. Med., 46, 784.

Crile, G. Jr., and Hazard, J. B. (1962). Surg. Gynec. Obstet., 115, 101.

Cureton, R. J. R., Harland, D. H. C., Hosford, J., and Pike, C. (1957). Brit. J. Surg., 44, 561.

Dick, A., and Kellett, H. S. (1951). Ibid., 39, 257.

Dinsmore, R. S., Dempsey, W. S., and Hazard, J. B. (1949). J. clin.

Doniach, I. (1960). In Recent Advances in Pathology, 7th ed., edited by Endocr., 9, 1043.

, Roitt, I. M., and Hudson, R. V. (1958). Lancet, 2, 265. C. V. Harrison, p. 197. Churchill, London.

Evans, R. W. (1956). Histological Appearances of Tumours. Livingstone, Edinburgh.

(1962) In Brit. Encyclop. Medical Pract. Medical Progress, edited by Lord Cohen of Birkenhead, p. 282. Butterworths, London.

Ewing, J. (1940). Neoplastic Diseases. A Treatise on Tumours, 4th ed. Saunders, Philadelphia and London.

Fulthorpe, A. I., Roitt, I. M., Doniach, D., and Couchman, K. E. (1961). J. clin. Path., 14, 654.

Goudie, R. B., Anderson, J. R., and Gray, K. G. (1959). J. Path. Bact., 77, 389.

Harrison, C. V. (1960). In Recent Advances in Pathology, 7th ed., edited by C. V. Harrison, p. 250. Churchill, London.

Kellett, H. S., and Sutherland, T. W. (1949). J. Path. Bact., 61, 233.

Kenyon, R., and Ackerman, L. V. (1955). Cancer (Philad.), 8, 964.

Lindsay, S., and Dailey, M. E. (1955). J. clin. Endocr , 15, 1332.

Lumb, G. (1954). Tumours of Lymphoid Tissue. Livingstone, Edinburgh and London.

Metcalfe, W. J., and Sclare, G. (1961). Brit. J. Surg., 48, 541.

Parsons, L. D. (1943). J. Path. Bact. 55, 397.

Rangström, S. (1957). Acta chir. scand., 113, 185.

Roitt, I. M., and Doniach, D. (1958). Lancet 2, 1027.

Roberts, L. (1961). Postgrad. med. J., 37, 481.

Scott, G. B. D. (1952). J. clin. Path., 5, 183.

Stewart A. E., and Allen, W. S. A. (1958). Lancet. 2. 47.

Walt, A. J., Woolner, L. B., and Black, B. M. (1957). J. clin. Endocr., $17,45$.

Warren, S., and Meissner, W. A. (1953). Tumors of Thyroid Gland. In Atlas of Tumor Pathology, sect. IV, Fasc. 14. Armed Forces Institute of Pathology, Washington D.C.

Welch, J. W., Chesky, V. E., and Hellwig, C. A. (1958). Surg. Gynec. Obstet., 106, 70.

Willis R. A. (1960). Pathology of Tumours. Butterworths, London. Winship, T., and Greene, R. (1955). Brit. J. Cancer, 9, 401.

Woolner, L. B., McConahey, W. M., and Beahrs, O. H. (1959). J. clin. Endocr., 19, 53. 